\title{
A Bond Stronger Than Marriage: Discipleship in the Works of Christopher Isherwood
}

\author{
Kinga Latała \\ Jagiellonian University in Kraków, Poland
}

This paper is concerned with Christopher Isherwood's portrayal of his guru-disciple relationship with Swami Prabhavananda, situating it in the tradition of discipleship, which dates back to antiquity. It discusses Isherwood's (auto)biographical works as records of his spiritual journey, influenced by his guru. The main focus of the study is My Guru and His Disciple, a memoir of the author and his spiritual master, which is one of Isherwood's lesser-known books. The paper attempts to examine the way in which a commemorative portrait of the guru, suggested by the title, is incorporated into an account of Isherwood's own spiritual development. It discusses the sources of Isherwood's initial prejudice against religion, as well as his journey towards embracing it. It also analyses the facets of Isherwood and Prabhavananda's guru-disciple relationship, which went beyond a purely religious arrangement. Moreover, the paper examines the relationship between homosexuality and religion and intellectualism and religion, the role of E. M. Forster as Isherwood's secular guru, the question of colonial prejudice, as well as the reception of Isherwood's conversion to Vedanta and his religious works.

\section{Keywords}

Christopher Isherwood; Swami Prabhavananda; My Guru and His Disciple; discipleship; guru; memoir

The present paper sets out to explore Christopher Isherwood's depiction of discipleship in My Guru and His Disciple (1980), as well as relevant diary entries and letters. Although Isherwood's involvement with Vedanta ${ }^{1}$ has been steadily gaining prominence in scholarly circles in recent years, it still remains obscure in the public consciousness. While sceptical of being labelled a homosexual writer on account of his most popular novel $A$ Single Man, he agreed that he was a religious writer (Geherin 152-153). Some scholars, including Wade (Christopher Isherwood, "Christophananda...") and Marsh ("On 'The Problem of the Religious Novel'...," Mr Isherwood...), advocate for Isherwood to be 
more commonly recognized as such. Marsh claims that there are two sources of Isherwood's reputation: his Berlin fiction and his literary contribution to the gay rights movement ( $M r$ Isherwood $\ldots 7$ ). This was reinforced by Cabaret (1972) and A Single Man (2009), two very successful films based on Isherwood's works, corresponding to these two spheres of his influence. His engagement with religion in his writings as well as his guru-disciple relationship with Swami Prabhavananda ${ }^{2}$ remain underrepresented, hence more studies are needed to investigate these aspects of his life and work.

\section{Discipleship: Overview}

Isherwood's relationship with Swami Prabhavananda should be considered in its historical context. The concept of a guru-disciple relationship has its roots in antiquity and is fairly universal, occurring in all major religions (Christianity, Islam, Judaism, Buddhism, and Hinduism), as well as philosophical schools. The institution of a guru (also known as a master, mentor, guide, lama or sage) has played a fundamental role in the spread of religions and philosophies, ensuring the continuity of their influence over the years. Katz lists Jesus, Moses, Elijah, Krishna, and Mohammad as examples of such mystical models (269). Wach distinguishes between the teacher-student and the masterdisciple relationship, stating that the former is an impersonal and replaceable relationship, whereas the latter is personal and irreplaceable: "The disciple must be touched to the core by his personality. The beloved master must be an essential part of his own existence" (1-2). Masters are especially relevant to the present discussion; however, often the distinction is hard to draw.

In ancient Egypt scribes performed the function of a sage, imparting their wisdom on their pupils (Williams 19). In ancient Sumer sages were educators and humanists who also served in the temple and in the palace (Kramer 32). In the Hebrew tradition the Torah is passed on orally from the Rabbinic sages to their disciples, influencing "traditions of domestic custom, liturgy, and theological imagination" (Jaffee 528,533 ). Neusner argues that disciples' tales of their rabbis did not have a biographical character, instead serving as expositions of collective values (188-189). When it comes to Christianity, Jesus functions as the paramount master, with the Apostles as his direct and the Evangelists as his indirect disciples. Moreover, the Church, even in modern times, is seen as "the community of disciples" (Cornille 869). In Buddhism, upon his transformation from Gotama, Buddha was tempted to keep his newly 
acquired wisdom to himself but eventually agreed to share it with others, thus becoming "the divine master" (Wach 6-7). Buddhist disciples submit to the lama with a view to becoming lamas themselves (Capper 53, 60). In Sufism (mystical Islam) the guide is described in parental and erotic terms: as the father of a disciple, representing authority, as the mother, spiritually nurturing a disciple, or as a lover, impregnating a disciple with knowledge (Malamud 89-9o). Guides were spiritually descended from Muhammad, the original master (Malamud 91). The most famous example of discipleship in ancient Greece is Socrates and his disciples. Graham lists the following disciples of Socrates: Antisthenes, Aeschines, Euclides, Aristippus, Plato, and Xenophon, out of whom only the last two are now well known for their association with Socrates (141). Socrates was condemned to death on the grounds of corrupting the youth and impiety (Mintz 742). Subsequently, his teachings were disseminated by Plato in the Dialogues and Xenophon in Memorabilia (Votaw 218-219). Plato's Socrates is a "midwife" who helps his disciples "give birth" to their ideas (Edmonds III 266).

Finally, in Advaita ${ }^{3}$ Vedanta, of which Isherwood was a practitioner, "discipleship is oriented toward attaining liberation (maksha) through complete surrender to a spiritual master or guru" (Cornille 878). Etymologically, the guru is "a dispeller of ignorance" or the "one who calls" (Mlecko 33-34). The guru engages in the exegesis of the scriptures and teaches by example (Mlecko 37). The importance of the guru was reinforced by Ramakrishna ${ }^{4}$ and his disciples in the $19^{\text {th }}$ century (Mlecko 52). Gurus are still popular in India and their "services" are advertised in the media (Warrier 31-32).

\section{Isherwood and Discipleship}

Isherwood had a lasting interest in mentor-disciple relationships and he liked to alternate between the two roles. Edward Upward was his early mentor, while Stephen Spender was his early pupil, shared with W. H. Auden. All of them were associated with the Auden group, whose self-proclaimed leader was Auden. Replogle, though, argues that "[a]part from Auden, these writers apparently never thought of themselves as a group ..." (135). Nevertheless, they shared an admiration for several modernist writers, such as Virginia Woolf, Katherine Mansfield, and E. M. Forster. Forster was especially important to Isherwood as an idol and friend; he was in fact his secular guru.

Isherwood states that as a young writer he saw himself as "a disciple of E. 
M. Forster" (Isherwood on Writing 151) and that "[i]n Forster he found a key to the whole art of writing" (Christopher and His Kind 105). Forster was twenty-five years his senior (a more considerable gap than the one between Isherwood and Prabhavananda) and had become a renowned novelist by the time Isherwood published his first novel in 1928. Forster let Isherwood read Maurice, his then unpublished novel with homosexual themes. "My memory sees them" - recalls Isherwood - "sitting together, facing each other. Christopher sits gazing at this master of their art, this great prophet of their tribe, who declares that there can be real love, love without limits or excuse, between two men" (Christopher and His Kind 126). In his letters to Forster, Isherwood frequently mentions Swami, referring to Forster's interest in India: "I do the ritual worship most days ... I think of you very often while I am doing it - you especially, because everything Indian suggests you to me - and sometimes I talk to the Lord about you" (Zeikowitz 112). Henig regards Forster as a significant contributor to the popularization of non-Western literature and culture $(76-77)$. Isherwood appreciated having a friend who would not sneer at Vedantist rituals and to whom he could talk freely about his devotion to Swami. "I would love to see you and Swami together - the two pillars of wisdom" - Isherwood wrote in 1946 (Zeikowitz 139). ${ }^{5}$ After Forster's death, Isherwood contemplated writing a joint memoir of his two mentors - "Tale of Two Gurus" (Liberation... 119).

This plan, however, did not come to fruition; Isherwood wrote a tale of only one guru: My Guru and His Disciple (first published in 1980). Isherwood considered writing a novel based on his relationship with Prabhavananda but eventually decided to write an (auto)biographical work. He contemplated several titles for the book: "Another Kind of Friend", "Guru and Disciple", "A Guru and His Disciple", "My Guru and His Disciple", and "Guru and Friend" (Liberation... 559, 598). His final choice is significant for two reasons: firstly, it signals the spiritual or philosophical nature of the relationship that is the subject of the book, and, secondly, it emphasizes the mutually binding character of such a union. The use of possessive pronouns ("my" and "his") indicates that the guru and disciple belong to each other as a consequence of the ritual of initiation. Finney claims that the title may be misleading, as Isherwood's attempt at self-effacement is contradicted by his focus on himself in the text (266). It is true that in My Guru and His Disciple Isherwood is largely preoccupied with himself: the disciple endeavours to pay respects to the man who has changed his life but the emerging portrait is mainly of himself. Nevertheless, he presents Swami as his point of reference and the source of his 
faith. Although Swami is not present in every scene, My Guru and His Disciple is a testimony of his enduring influence on Isherwood.

In terms of the genre, in most general terms, My Guru and His Disciple is a memoir. It depicts the author's own spiritual development, employing his own point of view, but always in relation to his mentor. Isherwood prefaces the book by saying that "[i]t is [his] one sided, highly subjective story of [their] guru-disciple relationship" (My Guru...). This double focus of My Guru and His Disciple proves a simple truth: a guru cannot be a guru without a disciple, just like a disciple cannot be a disciple without a guru. The book can be also regarded as a spiritual testimony or a conversion narrative. According to Smith and Watson, a conversion narrative features a drastic spiritual transformation (192). In the case of My Guru and His Disciple, conversion is at the core of the text; however, Isherwood recognizes that there is still a bumpy road towards enlightenment ahead of him. Spender remarks that "the essence of the confession is that the one who feels outcast pleads with humanity to relate his isolation to its wholeness" (44). As illustrated below, Isherwood's conversion was not well received; hence My Guru and His Disciple is an attempt at rectifying it.

Wade views Isherwood's Berlin fiction as an example of a minority writer writing for the majority (Christopher Isherwood 37). When it comes to My Guru and His Disciple, this positioning is even more pronounced, as here Isherwood simultaneously represents two minorities, each regarded with suspicion by the majority. Harker compares My Guru and His Disciple to Christopher and His Kind, Isherwood's most successful memoir, suggesting that they are both coming-out stories - the former as a Vedantist, and the latter as gay, each carrying a set of cultural implications (244). Indeed, My Guru and His Disciple is a statement about his spiritual journey as well as a public tribute to his guru, albeit one that did not have such an impact as Christopher and His Kind.

My Guru and His Disciple is comprised of diary entries and subsequent commentary. Therefore, using Smith and Watson's taxonomy of (auto)biographical "I"s (59), there are two narrating "I"s - the author of the diary entries and the author of the commentary. What is noteworthy, they are situated in two different points in time. The diary entries provide a more immediate and spontaneous response to Isherwood's experiences, while the commentary allows him to expand them and reflect on them more objectively. In addition, the commentary enables Isherwood to create a more cohesive and fluid narrative. 
Although My Guru and His Disciple is largely self-referential, it is also a traditional tribute to the guru by a disciple, reminiscent of St. Augustine's tribute to St. Ambrose in Confessions. In his diaries from the late 1970s, Isherwood consistently refers to it as a book about Swami. To establish the motives behind My Guru and His Disciple, it is worth considering its predecessors. Votaw discusses the prime examples of works written by disciples about their masters: the Socratic writings of Plato and Xenophon and the Gospels, which had two functions: the restoration of Socrates' and Jesus' reputations and preservation of their teachings (218-221). Isherwood does not seem to intend to convert his readers to Vedanta; "[i]t is my business to describe, not to dogmatize", he says (Vedanta... 11). Nevertheless, he is frustrated with "the mocking agnostics" who discredit the significance of the spiritual experience. My Guru and His Disciple was written "with a consciousness of the opposition and in answer to its prejudices" (Liberation... xxxiii). My Guru and His Disciple is thus a response to those who mistrust religion (particularly in its Eastern incarnations). Above all, though, My Guru and His Disciple is an attempt at establishing Prabhavananda as a saint who has exerted a tremendous influence on his seemingly unsaintlike disciple. As suggested by Bostick, both the Socratic writings and the Gospels "are written from the point of view of death and after-effects" (94). This is true in the case of My Guru and His Disciple, as Swami's death was the catalyst for Isherwood to share their story with the world in order to prove that their bond transcends death.

\section{An Unlikely Convert?}

Given Isherwood's rebellion against established institutions of authority, his conversion appears to be an uncharacteristic development. In order for the reader to better understand his choices, Isherwood depicts his internal turmoil upon his arrival in the USA in 1939. He attributes the despair and emptiness he experienced to the fact that "[he] had lost [his] political faith"; as a homosexual and pacifist, he could no longer subscribe to the left-wing ideology of his time (My Guru $\ldots 4){ }^{6}$ He was also aware of the hostility directed towards himself and W. H. Auden, who, according to their detractors, "had not simply left Britain" but "had abandoned Europe at the worst possible moment, just as it was about to plunge into war" (Monnickendam 130). He contrasts his disorientation with Auden's swifter adaptation to their new environment, 
concluding that Auden relied on his Christianity, "which he had never entirely abandoned", while he had nothing to fall back on (My Guru ... 5). In need of support, he turned to Gerald Heard and Aldous Huxley, his compatriots who had also emigrated to the USA. He approached their involvement with Hinduism with uneasiness, distancing himself from it:

To me, all this Oriental stuff was distasteful in the extreme. However, my distaste was quite different from the distaste I felt for the Christians. The Christians I saw as sour life-haters and sex-forbidders, hypocritically denying their secret lusts. The Hindus I saw as stridently emotional mysterymongers whose mumbo jumbo was ridiculous rather than sinister. (My Guru... 7)

His aggressive and condescending language is a clear indicator that at the time he was horrified at the thought of compromising one's independence and rationality for the sake of religion. The support he needed was purely intellectual, not spiritual, he asserts. Isherwood's initial dismissal of Hindu spirituality resembles Paul Zweig's impressions, recorded in his account of his guru-disciple relationship with Swami Muktananda: “... I felt suspicious of the florid orientalism ... It seemed so mindless, so foolishly exotic" (28). However, Isherwood soon acknowledged that Heard's pacifism and spirituality were interrelated. It was Heard's non-dogmatic approach to religion that lessened Isherwood's prejudice towards it. Since he no longer had to view it in Puritan terms, he was willing to explore it further.

In the summer of 1939 Heard accompanied Isherwood to his first meeting with Prabhavananda. The diary entry written after their second meeting reveals the tenderness Isherwood felt towards Swami: "His smile is extraordinary. It is somehow so touching, so open, so brilliant with joy that it makes me want to cry" (My Guru... 24). Isherwood notes that he felt inadequate in Swami's presence; nevertheless, he admitted to his religious scepticism. He told Prabhavananda that he feared that meditation would not mesh well with his lifestyle, that he could not take yoga seriously, and, above all, that he could not stand the word "God". Swami was not discouraged by his attitude; he used humour - a quality that Isherwood had formerly regarded as incompatible with religion - to make Isherwood more comfortable and made an effort not to alienate him, rephrasing religious concepts in terms that were more accessible to him. 
The issue that Isherwood considered critical was Swami's opinion about homosexuality, stressing that had Swami condemned it, it would have been a deal-breaker for him. Prabhavananda successfully passed the test:

... what convinced me that I could become his pupil-was that he hadn't shown the least shadow of distaste on hearing me admit to my homosexuality.

... I began to understand that the Swami did not think in terms of sins, as most Christians do. Certainly, he regarded my lust for Vernon as an obstacle to my spiritual progress-but no more and no less of an obstacle than lust for a woman, even for a lawfully wedded wife, would have been. (My Guru... 26)

As Marsh points out, Isherwood's turn to Vedanta should be considered in the context of the prevalent view of "the homosexual-as-a-religious-pariah" ( $\mathrm{Mr}$ Isherwood... 20). Swami's acceptance was therefore of utmost importance to Isherwood, as he was only willing to join a religion without any subterfuge and without being branded as a sinner from the outset. In comparison, Auden had to redefine his understanding of Christianity to accommodate his homosexuality. He regarded his relationship with Chester Kallman as a marriage and when he found out about Kallman's infidelity, "[h]e prayed to the God of his childhood that he might have agape if he could not have eros" (Farnan 22, 57). For Isherwood it was important to integrate his romantic relationships into his religious life more seamlessly.

Another fundamental aspect of Isherwood's relationship with Prabhavananda is the question of colonialism. In his seminal work Orientalism, Said maintains that "a European or American studying the Orient ... comes up against the Orient as a European or American first, as an individual second" (11). Isherwood openly acknowledges this aspect of his association with his guru. In 1939 Isherwood was still a British citizen ${ }^{7}$ who was about to willingly become a subordinate of a Bengali - a colonial subject. He recognizes the predicament of their position: "however hotly I might profess anti-imperialistic opinions, I was still an heir to Britain's guilt in her dealings with India" (My Guru ...36). Meeting Swami was not an antidote to the prejudice that was deeply ingrained in him; he admits that he considered Swami more of an exception than a representative of his country. This tension between Isherwood's fascination with Vedanta and his uneasiness with its rituals is tangible throughout My Guru 
and His Disciple but it does not eclipse its main focus, namely the importance of Prabhavananda for his spiritual journey.

Despite his conflicted attitude to India, Isherwood subverts the power relations between the colonizer and the colonized. Chatterjee remarks that "the relationship between Isherwood and the Swami was conducted on the ostensibly suprageographical, suprapolitical level of spirituality" (172). However, analysing a photograph in which the disciples - Isherwood and Heard - are situated below the guru, he suggests it may convey the impression of "the empire striking back" (Chatterjee 172). Similarly, ritual acts of devotion, such as prostrating before the guru and wiping the dust off his feet, performed by the disciple, gain a political significance when the disciple is British and the guru - Indian. My Guru and His Disciple shows that these two men, leading two different lives and pitted against each other by their origins, had a lasting and spiritually fulfilling guru-disciple relationship. According to Isherwood, "Vivekananda ${ }^{8}$ had two messages to deliver; one to the East, the other to the West" (Vedanta... 26); Isherwood and Prabhavananda embodied this coming together of two divergent spheres.

Interestingly, these "Oriental" elements that Isherwood could not fully embrace enabled him to relearn religious terms. So strong was Isherwood's reaction against Christianity that he could not use the English terms tarnished with "disgusting old associations with clergymen's sermons, schoolmasters' pep talks, politicians' patriotic speeches" (My Guru... 49). By his own admission, he "was suffering ... from a semantic block against the words which were associated with [his] upbringing" (What Vedanta Means to Me 48). By providing him with an alternative inventory of religious words, Sanskrit alleviated his prejudice against the spiritual sphere. For instance, Brahman, which Isherwood defines as "the Godhead ... Existence itself, Consciousness itself" (Vedanta... 2), was free from the associations carried by the English word "God". It was this linguistic defamiliarization, entailing an emotional detachment, that made it possible for Isherwood to become a believer. He discussed it with Auden, who had "a whole lingo of Christian theology, very abstruse. He said how much he disliked Sanskrit words. I told him I feel just the opposite" (Diaries: Volume One... 116). Nevertheless, he admits to "[s]torms of resentment-... against India, against the possibility of being given a Sanskrit name" (My Guru... 158). A Sanskrit name would be a threat to his identity and reputation. $\mathrm{He}$ considers such a prospect an invasion, "an act of hostile magic" (My Guru... 158). Struggling with his ego, he cannot abide the thought of relinquishing 
the name "Christopher Isherwood", thus equating it with his "self". .9 This is echoed in A Meeting by the River, when Oliver - an Englishman who is about to become a Hindu monk - says that his final vows mean that "Oliver must die" (A Meeting... 129). Isherwood's depiction of himself as a person strongly attached to his identity and independence makes his submission to the guru all the more significant. He admits to being surprised himself that despite his aversion to marriage, he "entered into a relationship with this little Bengali and his establishment which was far more serious and binding than a marriage" (My Guru... 66). Isherwood emphasizes that "the tie between the guru and his initiated disciple cannot be broken, either in this world or on any other future plane of existence, until the disciple realizes the Atman within himself and thus is set free", which he did not fully comprehend at the time of his initiation but which would bring him comfort later on (My Guru... 66).

In his discussion of Isherwood's Kathleen and Frank, Kusek points out Isherwood's preoccupation with the figure of his biological father Francis and the impact of his death in World War I on his life, which renders him a representative of "the generation of postmemory" (386). In the absence of his real father, Isherwood turned to his mentors. Although Prabhavananda was merely eleven years his senior, Isherwood treated him as a father. When Isherwood disappointed him, Swami said: "How should I not forgive you? You are my disciple and my child" (Liberation... 440).

In My Guru and His Disciple, conversion is not portrayed as the end of the struggle; after his initiation as Swami's disciple, Isherwood is faced with new challenges. If he wants to become a monk, he has to be celibate, maintain a routine of meditation and prayer, participate in the life of the congregation, and follow Vedantist rituals. Therefore, conversion is not a single act that ensures an instant transformation; it does not free Isherwood from doubt, restlessness, and confusion. He compares his doubts to being at sea, reassuring himself that "continuing to swim" is all that he needs to do (My Guru... 131). Faraone refers to this imagery of water, remarking that Swami "is the perfect kind of life vest to rescue Isherwood from the ocean of despair in which he has fallen" (181).

In My Guru and His Disciple, Isherwood introduces suspense about whether he will become a monk. Presenting himself as an altogether inadequate candidate for monastic life, he magnifies the solemnity of his last hours of unrestrained worldly life. Hollywood seems to exude glamour, entertainment, and romance. He savours the last moments before his monastic training, as though bidding farewell to the world: "But enough is enough. And here 
we say goodbye. / Or do we? Isn't this entirely the wrong spirit in which to become a monk?" (My Guru... 100). Isherwood depicts himself as an antisaint: temperamental, promiscuous, doubtful, prejudiced, neglectful, and lazy, juxtaposing himself with Prabhavananda, whom he considers a real saint. Isherwood was fascinated with the figure of a saint, defined as "a man, primarily, of experience - an experience which has led to enlightenment" (Isherwood on Writing 114).

However, contrary to what one may expect from a book written by a disciple and devoted to his master, My Guru and His Disciple is not distinctly eulogistic. Prabhavananda is neither free from human weaknesses, nor does he epitomize the ivory tower of detachment from the affairs of the world. Instead of showering Swami in verbal adulation, Isherwood proves Prabhavananda's value as a guru by documenting the development of his disciple, who did not become a monk, after all, but remained devoted to him for the rest of his life and used his literary talent to popularize Vedanta. ${ }^{\circ} \mathrm{He}$ proclaims that "the guru-disciple relationship is at the centre of everything that religion means to me. It is the only reality of which I am never in doubt" (What Vedanta Means to $\mathrm{Me}$ 49).

Isherwood recounts that on his own he acutely felt his "alienation from God" (Lost Years 278). Meditation is depicted as a chore but it is simultaneously Swami's answer to his troubles. Doubts linger and he even questions Swami about his faith. My Guru and His Disciple and his other (auto)biographical writings are not tales of a perfect disciple or unshakeable faith. They are testimonies of a challenging spiritual journey of an unlikely candidate for sainthood but whose guru believed otherwise. By depicting his internal struggles and the apprehension he felt about the reception of his involvement with Vedanta by others, Isherwood paints an authentic picture of a religious life. Moreover, he also emphasizes the power of his devotion to Swami, which endured his highs and lows. Isherwood acknowledges Prabhavananda's transformative effect on his life: "if I hadn't met him, my life would have been nothing" (My Guru ... 318).

It is apparent that Isherwood's religion relies predominantly on the influence of his guru. Swami is his guiding light and his link with the Brahman and Ramakrishna. As Copley remarks, "Isherwood indeed found himself as a consequence of the spiritual journey of his guru in a direct line of descent to Ramakrishna, for Prabhavananda's guru had been Brahmananda and Brahmananda's Ramakrisha himself" (183). Isherwood repeatedly emphasizes that his guru-disciple relationship with Swami is based on more than religion - 
that it is primarily a bond between two humans: "It doesn't matter what we talk about. He said, 'Come again soon. I like seeing you, Chris', and I told him I think about him all the time and have conversations with him in my mind. I was moved, as we parted, and felt shy" (My Guru... 218-219). Swami is not ashamed to tell Isherwood that he misses him and still hopes that he will follow his footsteps. When Isherwood confesses that he detests public preaching and worship because it diminishes the significance of his devotion to Prabhavananda, Swami replies: "I don't want to lose you, Chris" (The Sixties... 277). "The dialogue might have been spoken between lovers," claims Bucknell, pointing out the unconditional nature of Swami's love for his disciple (Introduction to The Sixties... xxvii). Isherwood feels that Swami's love is somehow different from romantic love: less self-conscious and complicated. In her analysis of $A$ Meeting by the River, Harker interprets Oliver's relationship with his guru as a "homosocial bond" that is "celibate but intimate" (242). This might also be true for Isherwood's relationship with Prabhavananda, as indicated by their acts of platonic intimacy (and dreaming of it on Isherwood's part):

His reverence for Prabhavananda as his guru inhibited him, but he was deeply happy when Prabhavananda occasionally hugged him. In most of Christopher's dreams about Prabhavananda, there were situations of physical (but altogether asexual) closeness - for example, they would be sharing a bedroom in a hotel, or Christopher would be helping Swami dress. (Lost Years 201)

Isherwood also relates moments of emotional vulnerability between them, for instance when Swami calls him to say that he shed tears while reading A Meeting by the River.

First and foremost, Isherwood depicts Swami as the anchor of his faith. In a letter to Forster, he remarks that "when you are with him you know that God exists" (Zeikowitz 97). Troubled by doubts, Isherwood seeks a confirmation of his faith in Swami's conviction about the existence of God: "I gradually ceased to be an atheist because I found myself unable to disbelieve in his belief in God" (Exhumations 115). The guru-disciple relationship endures Swami's death. In the final chapter of My Guru and His Disciple, Isherwood admits that his devotion to Hindu deities began to fade but his bond with Swami is not diminished. Therefore, Isherwood presents Swami as the centre of his religious experience and attests to the persistence of their mystical bond. 


\section{The Reception of Isherwood's Faith}

Bucknell argues that "[p]erhaps the widest gulf between Isherwood and his English friends was religious" (Introduction to Liberation... xxxii). Speaking on behalf of Isherwood's old friends, John Lehmann expresses their "dismay", "anxiety", and "mystification" at Isherwood's conversion, while Harold Nicolson attributes it to a "retreat" from the West (Carr 36-37). Isherwood was aware of his predicament of being misunderstood by both atheists and Christians. The philosopher Bertrand Russell, who, like Isherwood, had loose ties with the Bloomsbury group and who for some time belonged to his Los Angeles circle, proclaims: "I think all the great religions of the world - Buddhism, Hinduism, Christianity, Islam, and Communism - both untrue and harmful" (v). In his essay "Hypothesis and Belief" Isherwood attempts to rebuke the common belief that being an intellectual and a believer is mutually exclusive, claiming that " $\mathrm{t}]$ here is no conflict between true Religion and true Science" (Exhumations 119). By portraying spirituality as a rational choice, he defends his right to be both religious and intellectual. ${ }^{11}$

When it comes to Christianity, Isherwood's closest Christian friend was W. H. Auden. In their early youth Auden was a lapsed Anglo-Catholic; nevertheless he and Isherwood had confrontations about religion: "When Christopher raged against religion, Wystan would laugh and say, 'Careful, careful, my dear - if you keep going on like that, you'll have such a conversion, one of these days!'” (Christopher and His Kind 306). Auden's intuitions seem to have been accurate, at least to a degree; however, he probably could not have foreseen that it was Vedanta that Isherwood would turn to. As for Auden himself, he formally returned to his Christian faith in 1940 (Kirsch 21-22). Coincidentally, 1940 was also the year when Isherwood was initiated as a Vedantist. Auden's response to Isherwood's newfound beliefs resembles Isherwood's earlier dismissal of Auden's own faith: "'All this heathen mumbo jumbo - I'm sorry, my dear, but it just won't do'” (My Guru... 204). However, Murray remarks that in 1957 Auden challenged the claim that Eastern religions are "the errors of non-white folks" (277). The question of religion appears to have been a fundamental source of misunderstanding between these two lifelong friends. Theological differences aside, the vast impact of religion on their lives and works is not universally acknowledged, which may be attributed to the fallacious incongruity of religion and homosexuality.

Another Christian in Isherwood's life was one of his partners, William Caskey, for whom Isherwood abandoned his plans to become a monk. Caskey 
was Catholic and not interested in Vedanta, nonetheless Isherwood admired his resolve to persist in his faith yet not to conform to its view of sin. "We were both believers", states Isherwood, adding that when the occasion arose, they even prayed together (My Guru... 190). Isherwood shared a bond of believers also with Don Bachardy, his longest-standing partner. Unlike Caskey, though, Bachardy embraced Vedanta and was initiated by Prabhavananda. In his diary entry written on August 17, 1972, Isherwood contemplates the fact that his lover and himself are both disciples of Prabhavananda and meditate at the same time, concluding that "it is perhaps the most important feature of our whole relationship" (Liberation... 269).

\section{Conclusion}

My Guru and His Disciple is a memoir of a spiritual master and his follower. It testifies to Swami Prabhavananda's impact on Isherwood's life and constitutes a response to those who have underestimated or mocked Isherwood's involvement with Vedanta. By recording his doubts and temptations, Isherwood attempts to deliver an authentic portrayal of his chosen path. Moreover, he depicts Vedanta as a religion that enabled him to reconcile spirituality and homosexuality, instead of forcing him to choose one or the other. At the same time, his portrayal of discipleship in My Guru and His Disciple indicates that his devotion to his guru was of primary importance to him, which he confirms in his diary: "I personally am a devotee of Swami first and a Vedantist second" (Liberation... 224). This homosocial bond, which, according to Isherwood, endures death, is shown to resist colonial tensions, tantrums, doubts, and separations. It is at the same time a relationship between guru and disciple, father and son, and two intimate friends. Consequently, it extends beyond the traditional models of a guru-disciple relationship. Regarded by Isherwood as his "most worthwhile book" (Liberation... 650), My Guru and His Disciple is nonetheless one of his lesser-known works. It deserves more attention as a text that gives us an insight into the more obscure years of Isherwood's career as well as into the extent of the influence of Swami Prabhavananda and Vedanta on his life and later works. 


\section{Notes}

1. Isherwood maintains that the name "Vedanta" is more accurate than "Hinduism" (Vedanta... 1).

2. Originally Abanindra Nath Ghosh.

3. Non-dualist (Torwesten 225).

4. Ramakrishna (1836-1886) sparked "the so-called Hindu Renaissance" (Torwesten 169). Swami Prabhavananda was a member of the Ramakrishna Order.

5. Forster eventually met Prabhavananda in 1953 .

6. In a 1976 interview Isherwood says that: "my Leftism came into a clash with the fact that the Communists were starting to persecute the gays, after declaring earlier that they respected individual freedom in sexual matters" (Heilbrun 260).

7. He became an American citizen in 1946.

8. The founder of the Ramakrishna Order and the Ramakrishna Mission (Vedanta... 26).

9. Isherwood explains that you can only realize your "essential nature" (the Atman) by "ceasing to be yourself" (Vedanta $\ldots 4)$.

10. Isherwood was the author of Ramakrishna and His Disciples, and "Vedanta and the West" (included in Exhumations), as well as a contributor to Vedanta for the Western World, An Approach to Vedanta, Vedanta for Modern Man, and What Vedanta Means to Me. Together with Swami Prabhavananda he also translated The Yoga Aphorisms of Patanjali, Shankara's Crest-Fewel of Discrimination, and The Bhagavad-Gita.

11. It is especially relevant considering Isherwood's choice of religion. Sen asserts that India is often represented in the West as irrational, in contrast to the supposed western rationality $(69)$.

\section{Works Cited}

Bostick, Adelaide P. "A Comparison of the Portrait of Jesus in The Gospels with the Portrait of Socrates in the Writings of Plato and Xenophon." Fournal of the American Academy of Religion, vol. 3. 1935: 94-101. Print.

Bucknell, Katherine. "Introduction." Liberation: Diaries, by Christopher Isherwood. Ed. Katherine Bucknell. London: Chatto \& Windus, 2012. xiv-xl. Print.

---. Introduction. The Sixties: Diaries 1960-1969, by Christopher Isherwood. Ed. Katherine Bucknell. New York: Harper Perennial, 2011. xi-xxxvii. Print.

Capper, Daniel. "Devotion to Tibetan Lamas, Self Psychology, and Healing in the United States." American fournal of Pastoral Counseling, vol. 7, no. 3. 2004: 51-71. Print.

Carr, Jamie M. Queer Times: Christopher Isherwood's Modernity. New York: Routledge, 2013. Print.

Chatterjee, Niladri R. "'Give me devotion ... even against my will': Christopher Isherwood and India." The American Isherwood. Eds. James J. Berg and 
Chris Freeman. Minneapolis: University of Minnesota Press, 2015 171-178. Print.

Copley, Antony. A Spiritual Bloomsbury: Hinduism and Homosexuality in the Lives and Writings of Edward Carpenter, E.M. Forster, and Christopher Isherwood. Lexington: Lexington Books, 2006. Print.

Cornille, Catherine. "Discipleship in Hindu-Christian Comparative Theology." Theological Studies, vol. 77, no. 4. 2016: 869-885. Print.

Edmonds III, Radcliffe G. "Socrates the Beautiful: Role Reversal and Midwifery in Plato's Symposium." Transactions of the American Philological Association (1974-), vol. 130. 2000: 261-285. Print.

Faraone, Mario. "Spiritual Searching in Isherwood's Artistic Production." The American Isherwood. Eds. James J. Berg and Chris Freeman. Minneapolis: University of Minnesota Press, 2015: 179-192. Print.

Farnan, Dorothy J. Auden in Love. New York: Simon \& Schuster, 1984. Print. Finney, Brian. "My Guru and His Disciple." English, vol. 29., no. 135. 1980: 266-271. Print.

Geherin, David J. "An Interview with Christopher Isherwood." The fournal of Narrative Technique, vol. 2, no. 3. 1972: 143-158. Print.

Graham, Daniel. "Socrates and Plato." Phronesis, vol. 37, no. 2. 1992: 141-165. Print.

Harker, Jaime. "'A Life Entirely without Fear': Hindus, Homos, and Gay Pulp in Christopher Isherwood's A Meeting by the River." Gay Pulp Fiction: The Misplaced Heritage. Eds. Drewey Wayne Gunn and Jaime Harker. Amherst: University of Massachusetts Press, 2013. 229-247. Print.

Heilbrun, Carolyn G. "Christopher Isherwood: An Interview." Treentieth Century Literature, vol. 22, no. 3. 1976: 253-263. Print.

Henig, Suzanne. "The Bloomsbury Group and Non-Western Literature." Fournal of South Asian Literature, vol. 10, no. 1. 1974: 73-82. Print.

Isherwood, Christopher. A Meeting by the River. New York: Farrar, Straus and Giroux, 2013. Print.

---. Christopher and His Kind. New York: Farrar, Straus and Giroux, 2015. Print.

--- Diaries: Volume One: 1939-196o. Ed. Katherine Bucknell. London: Methuen, 1996. Print.

---. Exhumations. Harmondsworth: Penguin Books, 1969. Print.

---. Introduction. Vedanta for the Western World. Ed. Christopher Isherwood. London: George Allen \& Unwin Ltd, 1948. 1-28. Print. 
---. Isherwood on Writing. Ed. by James J. Berg. Minneapolis: University of Minnesota Press, 2007. Print.

---. Liberation: Diaries. Ed. by Katherine Bucknell. London: Chatto \& Windus, 2012. Print.

---. Lost Years: A Memoir, 1945-1951. New York: HarperCollins, 2007. Print.

---. My Guru and His Disciple. Harmondsworth: Penguin Books, 1981. Print.

---. The Sixties: Diaries 1960-1969. Ed. by Katherine Bucknell. New York: Harper Perennial, 2011. Print.

---. What Vedanta Means to Me. Ed. John Yale. London: Rider \& Company, 1961. 38-49. Print.

Jaffee, Martin S. "A Rabbinic Ontology of the Written and Spoken Word: On Discipleship, Transformative Knowledge, and the Living Texts of Oral Torah." Journal of the American Academy of Religion, vol. 65, no. 3. 1997: 525-549. Print.

Katz, Steven T. "Models, modeling and mystical training." Religion, vol. 12, no. 3. 1982: 247-275. Print.

Kirsch, Arthur. Auden and Christianity. New Haven: Yale University Press, 2005. Print.

Kramer, Samuel Noah. "The Sage in Sumerian Literature: A Composite Portrait." The Sage in Israel and the Ancient Near East. Eds. John G. Gammie and Leo G. Perdue. Winona Lake: Eisenbrauns, 1990. 31-44. Print.

Kusek, Robert. “Trucizna płynąca w moich żyłach”: postpamięć Wielkiej Wojny we współczesnych narracjach (auto)biograficznych." Przeglad Kulturoznawczy, vol. 22, no. 4. 2014: 383-395. Print.

Malamud, Margaret. "Gender and Spiritual Self-Fashioning: The MasterDisciple Relationship in Classical Sufism." Fournal of the American Academy of Religion, vol. LXIV, no. 1. 1996: 89-117. Print.

Marsh, Victor. Mr Isherwood Changes Trains, e-book. Bayswater: Port Campbell Press, 2011.

--.. "On 'The Problem of the Religious Novel': Christopher Isherwood and A Single Man." Literature and Theology, vol. 24, no. 4. 2010: 378-396. Print.

Mintz, Avi I. "Why did Socrates Deny that he was a Teacher? Locating Socrates among the new educators and the traditional education in Plato's Apology of Socrates." Educational Philosophy and Theory, vol. 46, no. 7. 2014: 735-747. Print.

Mlecko, Joel D. "The Guru in Hindu Tradition." Numen, vol. 29, no. 1. 1982: 33-61. Print. 
Monnickendam, Andrew. "Goodbye to Isherwood: The Rise and Fall of a Literary Reputation." Atlantis, vol. 30, no. 2. 2008: 125-137. Print.

Murray, Chris. "Coleridge, Isherwood and Hindu Light." Romanticism: The Fournal of Romantic Culture and Criticism, vol. 22, no. 3. 2016: 269-278. Print.

Neusner, Jacob. "Death-Scenes and Farewell Stories: An Aspect of the MasterDisciple Relationship in Mark and in Some Talmudic Tales." The Harvard Theological Review, vol. 79, no. 1. 1986: 187-197. Print.

Replogle, Justin. "The Auden Group." Wisconsin Studies in Contemporary Literature, vol. 5, no. 2. 1964: 133-150. Print.

Russell, Bertrand. Why I Am Not a Christian: And Other Essays on Religion and Related Subjects. Ed. Paul Edwards. New York: Simon \& Schuster, 1967. Print.

Said, Edward. Orientalism. New York: Vintage Books, 1979. Print.

Sen, Amartya. "Indian Traditions and the Western Imagination." Daedalus, vol. 126, no. 2. 1997: 1-26. Print.

Smith, Sidonie, and Julia Watson. Reading Autobiography. Minneapolis: University of Minnesota Press, 2001. Print.

Spender, Stephen. "Confessions and Autobiography." Autobiography: Essays Theoretical and Critical. Ed. James Olney. Princeton: Princeton University Press, 1980. 115-122. Print.

Torwesten, Hans. Vedanta: Heart of Hinduism. Ed. Loly Rossett. Translated by John Phillips. New York: Grove Press, 1991. Print.

Votaw, Clyde Weber. "The Gospels and Contemporary Biographies." The American Fournal of Theology, vol. 19, no. 1. 1915: 45-73. Print.

Wach, Joachim. "Master and Disciple: Two Religio-Sociological Studies." The Journal of Religion, vol. 42, no. 1. 1962: 1-21. Print.

Wade, Stephen. "Christophananda Writes His Religion: Isherwood's Purgatory." Critical Survey, vol. 13, no. 3. 2001: 3-18. Print.

---. Christopher Isherwood. London: Greenwich Exchange, 1991. Print.

Warrier, Maya. "Guru Choice and Spiritual Seeking in Contemporary India." International fournal of Hindu Studies, vol. 7, no. 1. 2003: 31-54. Print.

Williams, Ronald J. "The Sage in Egyptian Literature." The Sage in Israel and the Ancient Near East. Eds. John G. Gammie and Leo G. Perdue. Winona Lake: Eisenbrauns, 1990. 19-30. Print.

Zeikowitz, Richard E. (Ed). Letters Between Forster and Isherwood on Homosexuality and Literature. London: Palgrave Macmillan, 2008. Print. 
Zweig, Paul. "On Discipleship." The American Poetry Review, vol. 8, no. 6. 1979: 28-32. Print.

KINGA LATAŁA is a PhD student in the Department of Comparative Studies in Literature and Culture at the Institute of English Studies, Jagiellonian University in Kraków. Her research interests include World War I and the interwar period in literature, focusing on the autobiographical writings of Siegfried Sassoon and Christopher Isherwood, as well as humour in the works of P. G. Wodehouse in the context of translation studies.

kinga.latala@doctoral.uj.edu.pl 